TAPROBANICA, ISSN 1800-427X. June, 2014. Vol. 06, No. 01: pp. 59.

(C) Research Center for Climate Change, University of Indonesia, Depok, Indonesia \& Taprobanica Private Limited, Homagama, Sri Lanka http://www.sljol.info/index.php/tapro

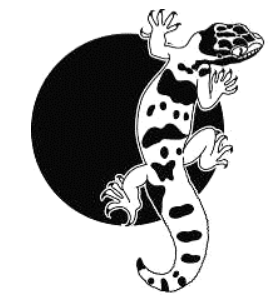

\section{Ceratophora stoddartii from Kegalle District (Sabaragamuwa Province), Sri Lanka}

The rhino-horned lizard Ceratophora stoddartii Gray, 1835 is endemic to Sri Lanka and is locally considered as Endangered (MOE, 2012). It is found in several montane and submontane habitats: Horton Plains, Hakgala, Namunukula Peak, Peak Wilderness, Haputale, Nuwara Eliya, Maratenna, Balangoda, Pattipola, Pidurutalagala, Ohiya, Kandapola, and Galaha (Manamendra-Arachchi \& Liyanage, 1994; Pethiyagoda \& ManamendraArachchi, 1998; Somaweera \& Somaweera, 2009). This slow moving lizard has been previously recorded around $1200-2200 \mathrm{~m}$ asl. (Bahir \& Surasinghe, 2005). During JanuaryAugust 2012 we observed ten (four adult males, five adult females and a juvenile) individual lizards at the Moratiya Estate (Maligawa Kanda) forest (near Dothalu-oya), Aranayake, (Kegalle District) Sri Lanka $\left(7^{\circ} 07^{\prime} 10^{\prime} \mathrm{N}\right.$, $\left.80^{\circ} 26^{\prime} 28^{\prime \prime} \mathrm{E}\right)$ at an elevation of $\sim 1000 \mathrm{~m}$. This is the first record of this species from Kegalle District. The habitat is geographically isolated from the Hatton plateau of the central highlands by a series of valleys and consists of submontane vegetation. The nearest previously recorded location is Galaha which is $30 \mathrm{~km}$ direct distance away in a northeasterly direction. The females at the Moratiya Estate were $78.2-81.1 \mathrm{~mm}$ SVL $(2.8-4.1 \mathrm{~mm}$ horn length). The males were $72.7-81.2 \mathrm{~mm}$ SVL (4.8-6.6mm horn length). All the adult individuals were found on the forest floor and the juvenile on a Strobilanthes leaf $\sim 50 \mathrm{~cm}$ above the ground. The species identification was confirmed based on Pethiyagoda \& Manamendra-Arachchi (1998). The Moratiya Estate forest is threatened by logging, manmade fire and the converting of forest to tea growing.

\section{Acknowledgements}

We thank L. J. M. Wickramasinghe, A. Silva, R. Somaweera, K. Manamendra-Arachchi, S. S. Fernando, and T. D. Surasinghe for providing literature and comments; John Rudge and M. M. Bahir for reviewing the manuscript.

\section{Literature Cited}

Bahir, M. M. and T. Surasinghe, 2005. A conservation assessment of the Sri Lankan Agamidae (Reptilia: Sauria). The Raffles Bulletin of Zoology, Supplement No. 12: 407-412.

Manamendra-Arachchi, K. and S. Liyanage. 1994. Conservation and distribution of the agamid lizards of Sri Lanka with illustrations of the extant species. Journal of South Asian Natural History, 1: 77-96.

Pethiyagoda, R. and K. Manamendra-Arachchi, 1998. A revision of the endemic Sri Lankan agamid lizard genus Ceratophora Gray, 1835, with description of two new species. Journal of South Asian Natural History, 3: 1-50.

Somaweera, R. and N. Somaweera, 2009. Lizards of Sri Lanka: A colour guide with field keys. Chaimaira publications, Germany: 304.

MOE, 2012. The National Red List 2012 of Sri Lanka. Ministry of Environment, Colombo, Sri Lanka: 476.

Submitted: 11 Jan. 2014, Accepted: 18 March 2014 Section Editor: A. A. T. Amarasinghe

$$
\begin{array}{r}
\text { U. S. C. Udagedara }{ }^{1} \text { \& K. A. P. M. K } \\
\text { Karunarathna }
\end{array}
$$

Sri Lanka E-mail: uscudagedara@gmail.com

${ }^{2}$ Sandaraja Wana Arana, Dothalu-oya, Dolosbage, Sri Lanka 